\title{
Seasonal and interannual correlations between right-whale distribution and calving success and chlorophyll concentrations in the Gulf of Maine, USA
}

\author{
Brittan L. Hlista1, Heidi M. Sosik ${ }^{1, *}$, Linda V. Martin Traykovski ${ }^{1}$, \\ Robert D. Kenney ${ }^{2}$, Michael J. Moore ${ }^{1}$
}

\author{
${ }^{1}$ Biology Department, Woods Hole Oceanographic Institution, Woods Hole, Massachusetts 02543, USA \\ ${ }^{2}$ Graduate School of Oceanography, University of Rhode Island, Narragansett, Rhode Island 02882-1197, USA
}

\begin{abstract}
The North Atlantic right whale Eubalaena glacialis is one of the most endangered species of large whales. Although human-caused mortality is the primary factor contributing to poor recovery of E. glacialis, variability in reproductive success may also play a role. The present study evaluates the idea that seasonal distributions and reproductive success in E. glacialis are linked to food availability or related environmental conditions that can be assessed by treating satellitederived sea-surface chlorophyll (chl) concentration as a proxy. Sea-surface chl time series in the major high-use feeding habitats and whale-sightings data were compared. Whale transition between habitats reflects a pattern in the seasonal distribution of peak concentration in satellite-derived chl. A regionally and seasonally weighted chl index was calculated to reflect aspects of average potential food condition. We found a significant correlation between the number of whale calves born and the weighted chl averaged over the prior $2 \mathrm{yr}$. These findings are consistent with the view that food availability during and just before the gestation period may be a critical factor regulating reproductive success, with low food years contributing to delays in conception. Longer time series are necessary to examine the predictive relationship between weighted chl concentration and calf production. Although ecological interactions and whale reproductive biology are certainly more complex than can be encompassed by emphasizing only food availability, analysis of satellite-derived surface chl concentrations provides a practical means to monitor a level of ecosystem variability that affects right-whale distributions and productivity.
\end{abstract}

KEY WORDS: Right whale · Eubalaena glacialis $\cdot$ Calving $\cdot$ Seasonal patterns · Ocean color SeaWiFS $\cdot$ Chlorophyll $\cdot$ Remote sensing

\section{INTRODUCTION}

As a consequence of the whaling industry, the North Atlantic right whale Eubalaena glacialis population was reduced to very low levels by the end of the 19th century and its current population is estimated at $<400$ ind. (IWC 2001, Kraus et al. 2005). Despite international protection from commercial whaling since 1935, the population is showing slow signs of recovery, at best. Demographic estimates have indicated a gradual decline in the population growth rate from about
$5.3 \%$ in 1980 to $-2.4 \%$ in 1994 (Caswell et al. 1999). Overall, the E. glacialis population growth rate is extremely low $(<1 \%$ since 1992; Fujiwara \& Caswell 2001). The 2 major anthropogenic sources of rightwhale mortality include vessel strikes and entanglement with fixed fishing gear (Knowlton \& Kraus 2001). Although anthropogenic mortality compromises the recovery of this population, strong evidence suggests that a variable reproductive rate (Knowlton et al. 1994, Kraus et al. 2001) and a calving interval that fluctuates from 3 to 6 yr (Kraus et al. 2007) also contribute to the 
reduced population growth rate. The factors that could contribute to decreases in reproductive rate include environmental contaminants, body condition/ nutritional stress, loss of genetic variability, infectious disease, and marine biotoxins (Reeves et al. 2001). The present study examines the idea that reproductive success in E. glacialis is linked to food availability and evaluates satellite-derived sea-surface chlorophyll (chl) concentration as an environmental proxy for the nutritional potential of right-whale feeding grounds.

The relationship between nutrition and reproduction in female mammals has been well documented for a number of species. In terrestrial mammals, body fat impacts fertility by supplying the necessary energy for reproduction and for sexual maturation (Frisch 1984, Thomas 1990). In the North Atlantic fin whale Balaenoptera physalus, Lockyer (1986) found that an apparent body-fat enhancement paralleled an increase in food supply and appeared to be associated with increased fecundity. For Eubalaena glacialis, blubber thickness can be measured acoustically in the field (Moore et al. 2001) and poor body condition, as indicated by low blubber thickness, has been correlated with poor reproductive success. Angell (2005) found that blubber thickness in reproductively active female right whales decreased during lactation, increased after weaning, and was thickest several months prior to the start of pregnancy. This result emphasizes that females utilize their blubber reserves for energetic support during reproduction, and argues for the importance of evaluating nutritional factors in regulating the reproductive success of this species.

A thorough evaluation of right-whale population dynamics requires a better understanding of the spatial and temporal variability of the whales' food supply. Numerous studies (Murison \& Gaskin 1989, Mayo \& Marx 1990, Kenney \& Wishner 1995, Wishner et al. 1995, Beardsley et al. 1996, Woodley \& Gaskin 1996, Baumgartner \& Mate 2003) conducted in each of the major feeding habitats in the western North Atlantic have demonstrated that a single species of zooplankton, the 2 to $3 \mathrm{~mm}$ long calanoid copepod Calanus finmarchicus, particularly late-stage copepodites, is the primary prey.

Recent studies have demonstrated that the abundance and distribution of phytoplankton can directly affect egg production rates (Campbell et al. 2001) and development (Crain \& Miller 2001) of Calanus finmarchicus. For example, Campbell et al. (2001) showed that in areas of higher chl concentration, early copepodite stages were larger and in better condition than copepodites found in nearby areas with lower chl concentration. Phytoplankton blooms can have a direct effect on the late copepodite stages as well, especially if they persist for some time (Durbin et al. 2003). For instance, an anomalous winter bloom across the Gulf of Maine in late February 1999 may have allowed an extra generation of $C$. finmarchicus to develop, preceding the usual March-April spring bloom, thus leading to a substantial accumulation of the population (Durbin et al. 2003).

Food limitation due to low availability of phytoplankton has also been hypothesized as a source of Calanus finmarchicus mortality (Campbell et al. 2001), specifically in the naupliar stages that are more susceptible to starvation. Starvation in these early stages may ultimately limit the availability of high-quality right-whale food (Stage 4 and 5 copepodites) later in the season. Thus, those phytoplankton bloom conditions that favor the accumulation of the right whale's food source (C. finmarchicus) may in fact be directly beneficial for the whales, particularly for females, who must meet the demands of pregnancy and nursing, through either higher food intake or larger metabolic reserves.

Data on the variability in phytoplankton biomass provide a means to explore the hypothesis that food limitation of Calanus finmarchicus impacts the growth and survival of Eubalaena glacialis. Surface concentration of chl, the dominant photosynthetic pigment in phytoplankton, is widely used as an index of phytoplankton abundance and biomass. Because the right whale's zooplankton food source, C. finmarchicus, is only 1 trophic level above phytoplankton, the distribution and concentration of phytoplankton may reflect potential $C$. finmarchicus production over scales related to life-cycle progression and advective processes in the Gulf of Maine $(\sim 10$ s to 100 s of kilometer spatial scales and weekly to monthly time scales). Food available during and before the right whale's gestation period may be a critical factor regulating their reproductive success, but this is difficult to assess directly with conventional sampling approaches because of the large spatial ranges and extended periods of time involved in whale feeding behavior. Remote sensing approaches for examining the spatio-temporal distribution of phytoplankton biomass provide a practical means to explore a possible link between reproductive success in whales (calf production) and environmental conditions that may regulate their food supply.

Remotely sensed ocean-color data provide unique synoptic views of marine phytoplankton biomass over long periods of time and large horizontal expanses of the surface ocean, far beyond what can be assessed from shipboard measurements. Data acquired by the Sea-viewing Wide Field-of-view Sensor (SeaWiFS) since its launch in 1997 can be used to quantify the spatial and temporal variability of phytoplankton chl (a proxy for biomass) (e.g. O'Reilly et al. 1998). Chl estimated from ocean color is an imperfect proxy for total phytoplankon biomass for reasons ranging from vari- 
ability in the ratio of phytoplankton carbon to chl to the presence of subsurface chl layers ( 10 to $50 \mathrm{~m}$ depth) that can be below the penetration depth for satellite observations (Gordon \& Clark 1980) and may at times be important for regulating copepod distributions (e.g. Townsend et al. 1984). Despite these challenges, the advantages of mesoscale spatial and temporal coverage provided by ocean-color satellite sensors can be very important for exploring links between higher trophic levels and primary producers. For example, Platt et al. (2003) used SeaWiFS observations off Nova Scotia to provide compelling evidence that larval fish survival is linked to the timing of the spring bloom, an important piece of the long-standing match/mismatch hypothesis dealing with food availability at critical times after spawning (see Cushing 1975, 1990). These kinds of hypotheses cannot be tested adequately with conventional sampling approaches. The close trophic connection between right whales and phytoplankton and the advantages of satellite data have motivated us to explore the relationship between remotely sensed phytoplankton pigments, whale sightings, and calf production in the Northwest Atlantic.

Previous examinations of right-whale distributions and migratory patterns (Winn et al. 1986, Gaskin 1991, Kenney et al. 2001, Kraus et al. 2001) have shown that this species typically spends the period between January and October feeding in the Northwest Atlantic. Four primary feeding grounds (see Fig. 1) appear to be consistently utilized by right whales on a seasonal basis: (1) Cape Cod Bay, (2) Great South Channel, (3) the southern portion of the Bay of Fundy, and (4) the Roseway Basin portion of the shelf. The areal extent and the multi-year, multi-seasonal nature of any problem involving whale feeding effects emphasizes that satellite observations are the only way currently available to characterize phytoplankton variability on appropriate scales.

Previous studies have documented strong seasonality and interannual variability in chl distributions in the Gulf of Maine and surrounding areas (Yoder et al. 2002, Thomas et al. 2003). Furthermore, previous efforts to evaluate SeaWiFS retrievals support their use for examining variability in this region. As emphasized in analyses by Gregg \& Casey (2004), in situ chl observations for the Gulf of Maine region comprise a large fraction $(\sim 40 \%)$ of the available global data set for evaluation of SeaWiFS retrievals, and retrieval performance for this region is similar to the rest of the globe ( $32 \%$ RMS log error). Even in challenging sites such as semi-enclosed embayments of the Gulf of Maine, standard SeaWiFS retrievals are correlated with in situ values, though with some bias towards overestimates from the satellite (Hyde et al. 2007). Our goal was to build on this foundation to evaluate whether observed patterns in chl variability from SeaWiFS show any relationship to those of right-whale distributions and fecundity.

\section{MATERIALS AND METHODS}

We examined satellite-derived chl in the major 'high-use' feeding habitats of Cape Cod Bay, Great South Channel, Bay of Fundy, and Roseway Basin and compared patterns to those in right-whale distributions and annual calving rates. Our approach uses satellitederived ocean-color data for the Northwest Atlantic, the extensive right-whale sightings database for the region, and the photo-identification database of observed numbers of calves produced each year from 1998 to 2007.

Ocean-color processing. The SeaWiFS archive (August 1997 to December 2006) was obtained from NASA/Goddard Space Flight Center as daily Level 1A MLAC (Merged Local Area Coverage) and processed to high-resolution Level 2 products (chl concentration and normalized water-leaving radiance). During Level 2 processing, atmospheric corrections and bio-optical algorithms, OC4v4 (O'Reilly et al. 1998, 2000), were applied to the sensor data as implemented in SeaDAS (SeaWiFS Data Analysis System) version 4.9 (Fu et al. 1998), with flags optimized for the study area (masked pixels according to SeaDAS defaults, plus flags for high solar zenith and for low normalized water-leaving radiance at $555 \mathrm{~nm}$ ). On occasion, the satellite orbit configuration produced 2 scenes $\mathrm{d}^{-1}$, one of which was invariably at a wide scan angle resulting in distorted pixels. In these cases, the satellite orbits that produced images nearest nadir were kept in the data set and the distorted images were discarded, because the chl concentrations and distributions were unreliable. This processing resulted in daily scenes, spanning the entire period of 1997 to 2006, with gaps in time and space principally due to cloud cover. SeaWiFS algorithms are optimized for clear-water (Case 1) regions and chl retrievals have been validated to within 30 to $35 \%$ over the concentration range 0.01 to $64 \mathrm{mg} \mathrm{m}^{-3}$ for open-ocean and coastal environments (Hooker \& McClain 2000, Gregg \& Casey 2004, Lavender et al. 2004). In our analyses, we discarded retrieved chl values outside of this validation range.

Individual daily scenes were mapped to the NorthEast Coast projection (NEC) (see Fig. 1) at the highest resolution $\left(1 \mathrm{~km} \mathrm{pixel}^{-1}\right)$. The NEC projection is a standard used by the University of Rhode Island and National Oceanic and Atmospheric Administration (URI-NOAA) Remote Sensing Group. The resulting daily images were then used to produce weekly ( $8 \mathrm{~d}$ ) and monthly composites, by taking the geometric 
mean of the non-masked available chl concentrations for the entire region encompassing the Eubalaena glacialis feeding grounds in the Northwest Atlantic. Since the distribution of chl in shelf and slope waters approximately follows a log-normal distribution (Campbell 1995), the logarithms of chl concentrations were taken prior to calculating the composites.

Right-whale sightings distribution. The boundaries of 4 'high-use' areas within the feeding grounds were determined with data obtained from the North Atlantic Right Whale Consortium (NARWC) sightings database, maintained at URI (Kenney 2001). The full database of sightings records extends back to the 18th century and includes $>30000$ right-whale observations from aerial and shipboard surveys and opportunistic sources. The NARWC data set stored and processed at URI is regularly updated, but only observations from the available period of overlap with the available SeaWiFS remote sensing imagery (1997 to 2005) were analyzed for the present study.

Because of potential bias caused by uneven distribution of survey effort, we used the sightings per uniteffort (SPUE) algorithm developed at URI (CETAP 1982, Kenney \& Winn 1986, Shoop \& Kenney 1992) to provide a quantitative assessment of right-whale distributions. For the present study, all aerial and shipboard survey data, from the Gulf of Maine and surrounding waters (north of $39^{\circ} \mathrm{N}$ and west of $63^{\circ} \mathrm{W}$ ), were extracted from the NARWC data set to quantify sampling effort and derive right-whale SPUE values. The entire study region was partitioned spatially into a grid of cells measuring $3^{\prime}$ of latitude $(5.6 \mathrm{~km})$ by $3^{\prime}$ of longitude (3.9 to $4.3 \mathrm{~km}$ ) and temporally by month.

Survey effort was first quantified as the length of track sampled under acceptable survey conditions. Only track line segments completed with clear visibility of $\geq 2$ nautical miles $(3.7 \mathrm{~km})$, sea state $\leq$ Beaufort 3 , aircraft altitude $<1200$ feet $(366 \mathrm{~m})$, and $\geq 1$ observers on watch were included as acceptable effort. Similarly, only right whales sighted during acceptable effort were included and summed within each cell and month. Finally, the number of right whales sighted was divided by effort to generate the SPUE index, in units of whales sighted per $1000 \mathrm{~km}$ of valid effort.

These data were used to specify boundaries that reflect the most widely used feeding grounds around Cape Cod Bay, Great South Channel, Bay of Fundy, and Roseway Basin. Initially, areas substantially larger than the federally defined right-whale critical habitats (USA) or right-whale conservation areas (Canada) were created around each of the 4 feeding areas, such that all of the 1997 to 2005 sightings were included. Effort and sightings across all years and months were summed within each grid cell, and a single overall SPUE value per cell was computed. The non-zero
SPUE values were ordered from highest to lowest. Finally, smaller, rectangular high-use areas were defined without compromising the sightings data, to include grid cells that encompassed most of the highdensity SPUE and a large portion of the total SPUE (see Fig. 1).

Calving observations. The NARWC photo-identification catalog, curated by the New England Aquarium (NEA), contains $>41000$ sighting records of individual right whales as a result of intensive photographic identification efforts since 1980 (Hamilton \& Martin 1999). Because females usually give birth in the calving ground along the coast of Georgia and southeastern Florida, the photographic data resulting from intensive survey efforts in that area ( 90 aerial survey days $\mathrm{yr}^{-1}$ ) and in the northern feeding grounds where mothercalf pairs are also sighted captures most, if not all, calves in the population (Kraus et al. 2001). NEA provided summary data of annual calf count, calculated from the total number of mothers identified with calves for the years 1998 to 2007.

Time series. Composite satellite data were used to calculate time series of average chl concentration in each high-use area defined from the SPUE analysis. Data extracted from daily imagery with $\geq 15 \%$ valid pixels in each high-use area were used to create weekly and monthly time series over the entire period of available SeaWiFS data. Using this criterion, daily imagery for each of the high-use areas was available 80 to $100 \%$ of the time. On average, these weekly and monthly composites provided a spatial coverage of 86 and $96 \%$, respectively. By taking the mean of each month over the period 1997 to 2006, it was possible to produce mean annual cycles and explore differences in seasonal patterns between the areas of interest.

Since we wanted to explore general relationships between chl time series and right-whale sightings, monthly resolved SPUE data for each high-use area were also analyzed to produce mean annual cycles of whale distributions. These annual cycles were calculated in the same way as for the SeaWiFS data, i.e. by computing the mean for each month given all the observations over the period from 1997 to 2006.

Annual weighted chl (nutritional index). Initial findings relating seasonal patterns in mean annual chl and SPUE across the high-use areas were used to calculate a simple nutritional index to capture annual variations in chl that might be relevant to the right-whale population. With the goal of generating an index that reflects aspects of average potential food condition in each of the high-use areas during the season of peak sightings, we calculated a simple 2-stage average chl concentration. First, for a given year, chl was averaged over all of the pixels within each high-use area and over the period of relatively high concentration specific to each 
area (see details below). Then, the resulting values ( 1 for each of the 3 high-use areas; Roseway Basin was not included in the average due to sparsity of SPUE data) were averaged to obtain a single weighted-average chl concentration for the year. This value is weighted such that only the overlap between 'bloom' period and peak sightings is considered in a way that is specific to each high-use area defined by the SPUE analysis. For example, in Cape Cod Bay, only early months of the year contribute to the average because chl concentration and whale sightings tend to be highest in that period. A more complex average could reflect seasonal variability in prey composition or weightings that reflect habitat value (i.e. if one area was known to be a more important feeding ground than others, its contribution could be weighted more heavily). Given the lack of information to support the inclusion of these additional factors, however, we used a simple equal weight for each area.

To explore the relationship between the annual weighted chl and right-whale reproductive success (number of calves observed), we considered the effect of several time lags. Variations in food availability can be integrated over multiple years because females utilize their blubber reserves for energetic support during reproduction (Angell 2005) and $\geq 3$ yr are typically required between successive calving: 1 yr for lactation, a resting year to accumulate fat stores, and a gestation year (Knowlton et al. 1994). Thus, we evaluated 3 cases: (1) the nutritional index in the year prior to calving, (i.e. gestation), (2) the nutritional index $2 \mathrm{yr}$ prior to calving (i.e. resting), and (3) the mean of the nutritional index in both years prior to calving. In each case we used reduced major-axis Model II regression (Sokal \& Rohlf 1981) to summarize the relationships between chl and calf production.

\section{RESULTS}

\section{Right-whale sightings distributions}

The 4 high-use areas as defined by the analysis of the SPUE data delineate regions that encompass the most frequent right-whale sighting locales: in the vicinity of Cape Cod Bay, the Great South Channel, the Bay of Fundy, and Roseway Basin (Fig. 1). For the period 1997 to 2005, these defined areas exclude only 5 to $20 \%$ of the cumulative sightings (i.e. relatively rare sightings in surrounding areas). While the high-
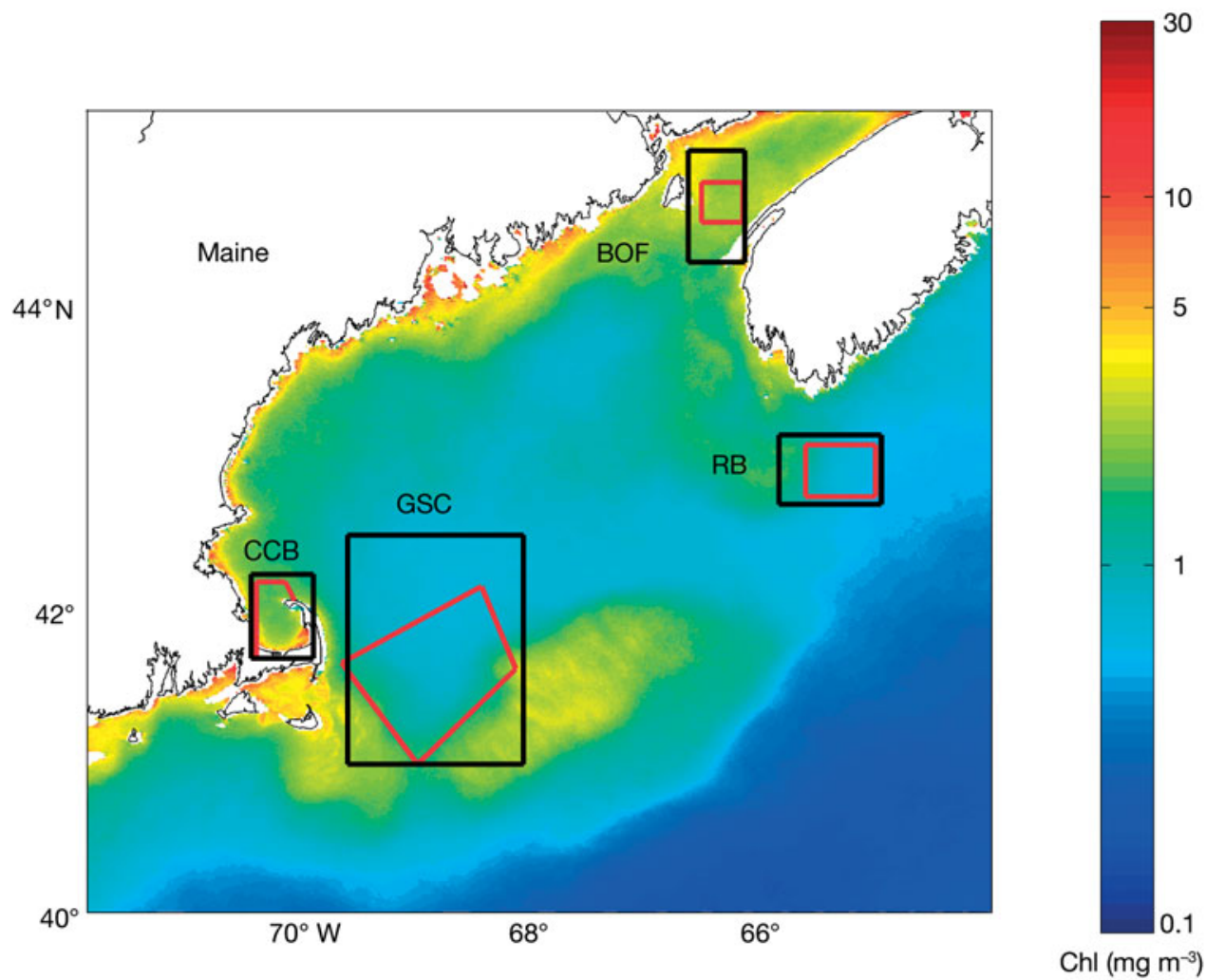

Fig. 1. High-use areas (black outline) defined by analysis of the sightings per unit effort (SPUE) data for North Atlantic right whales encompass the pre-existing critical habitat or conservation zones (red outline). Background image shows July monthly mean composite chlorophyll (chl) distribution from analysis of SeaWiFS observations. CCB: Cape Cod Bay, GSC: Great South Channel, BOF: Bay of Fundy, RB: Roseway Basin 
use areas we defined extend beyond the bounds currently designated as critical habitat (USA) or conservation zone (Canada) for the North Atlantic right whale

Table 1. Properties of the 4 high-use areas defined by analysis of sightings per unit effort (SPUE) data. Latitudes and longitudes for northern, southern, western, and eastern edges specify the areas

\begin{tabular}{|lcccrrr|}
\hline $\begin{array}{l}\text { High-use } \\
\text { area }\end{array}$ & North & South & West & East & $\begin{array}{r}\text { No. of } \\
\text { pixels }\end{array}$ & $\begin{array}{r}\text { Areal } \\
\text { extent } \\
\left(\mathrm{km}^{2}\right)\end{array}$ \\
\hline Cape Cod Bay & $42.25^{\circ} \mathrm{N}$ & $41.70^{\circ} \mathrm{N}$ & $70.55^{\circ} \mathrm{W}$ & $70.00^{\circ} \mathrm{W}$ & 1900 & 41 \\
Great South Channel & $42.50^{\circ} \mathrm{N}$ & $41.00^{\circ} \mathrm{N}$ & $69.70^{\circ} \mathrm{W}$ & $68.15^{\circ} \mathrm{W}$ & 14098 & 113 \\
Bay of Fundy & $44.95^{\circ} \mathrm{N}$ & $44.25^{\circ} \mathrm{N}$ & $66.70^{\circ} \mathrm{W}$ & $66.20^{\circ} \mathrm{W}$ & 2170 & 44 \\
Roseway Basin & $43.15^{\circ} \mathrm{N}$ & $42.70^{\circ} \mathrm{N}$ & $65.90^{\circ} \mathrm{W}$ & $65.00^{\circ} \mathrm{W}$ & 2356 & 46 \\
\hline
\end{tabular}
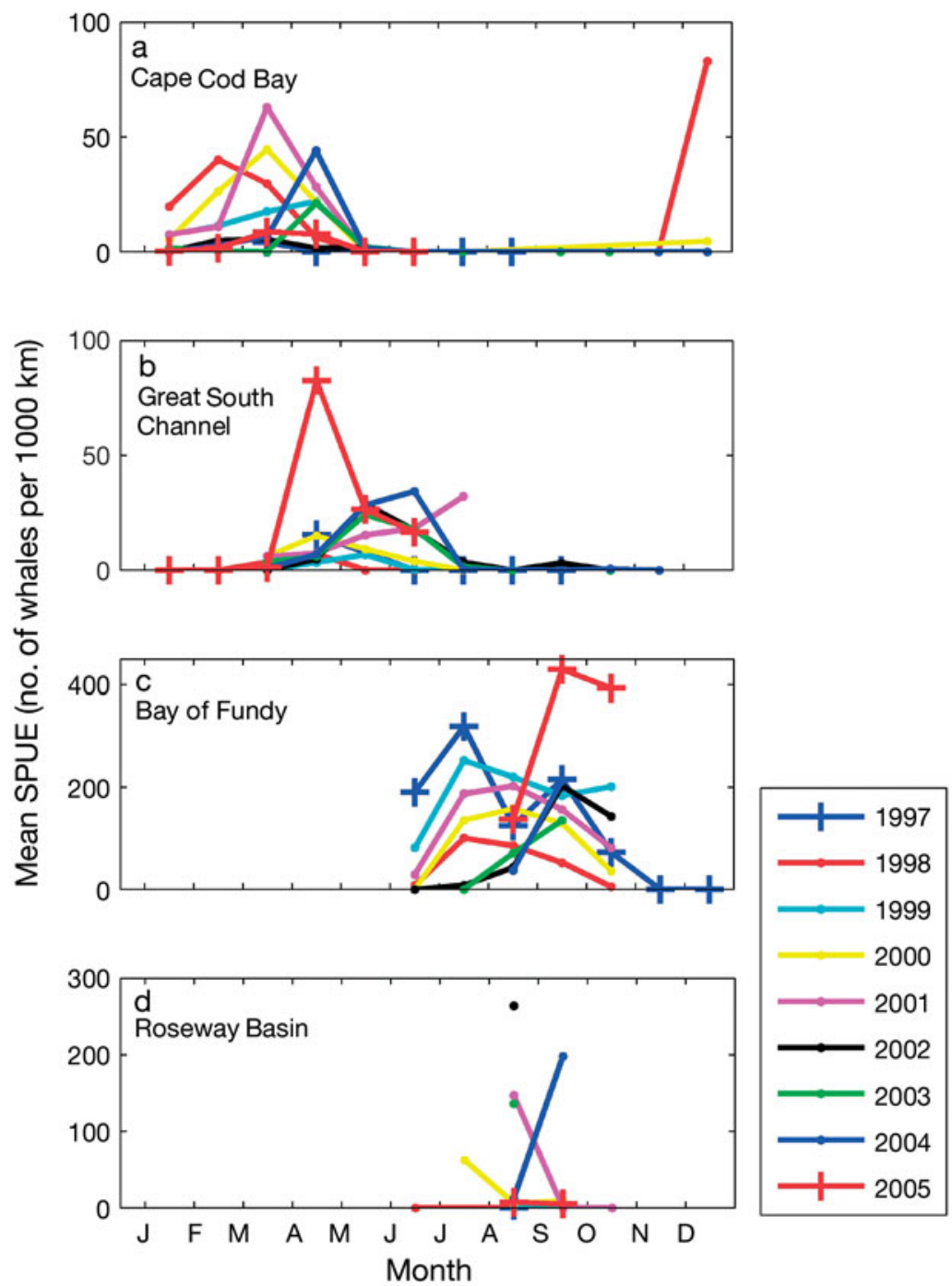

Fig. 2. Average right-whale sightings per unit effort (SPUE) in each high-use area: (a) Cape Cod Bay, (b) Great South Channel, (c) Bay of Fundy, and (d) Roseway Basin, for each year from 1997 to 2005
(Fig. 1, Table 1), they are consistent with previous analyses of the sightings database (Winn et al. 1986, Kenney et al. 2001).

Examination of average rightwhale SPUE for each year from 1997 to 2005 shows that, for each area, the arrival and departure of whales vary considerably from year to year (Fig. 2). From this analysis, it is also clear that arrivals and departures are not always well resolved on the basis of the first and last surveys of the season. It is important, however, to note that all years show a consistent pattern of transition from Cape Cod Bay (January to May) to the Great South Channel (March to June) to the Bay of Fundy (June to October) as the seasons progress from winter to summer (Fig. 3). This view is consistent with previous analyses of right-whale sightings distributions (Winn et al. 1986, Kenney \& Wishner 1995, Kenney et al. 2001).

Cape Cod Bay. SPUE data for the period from 1997 to 2005 show few whales present as early as November or December in Cape Cod Bay; these may represent early arrivals for the new feeding season or late departures (on their way southward) from the previous year (Allen 1916). An exception is 1998 when the mean SPUE was very high (83 whales per $1000 \mathrm{~km}$ in December), possibly associated with a shorterthan-usual survey that happened to coincide with high whale density. More typically, the SPUE data suggest the abundance of whales begins to increase in January and reaches a maximum between February and April. By May, right whales have consistently departed Cape Cod Bay (Figs. 2 \& 3).

Great South Channel. Interannual variability is notable in arrival and departure of whales from Great South Channel (Figs. 2 \& 3). Nonetheless, some generalities emerge. There are consistently few whales sighted in March and the observations suggest that most right whales begin arriving during April, peak in 

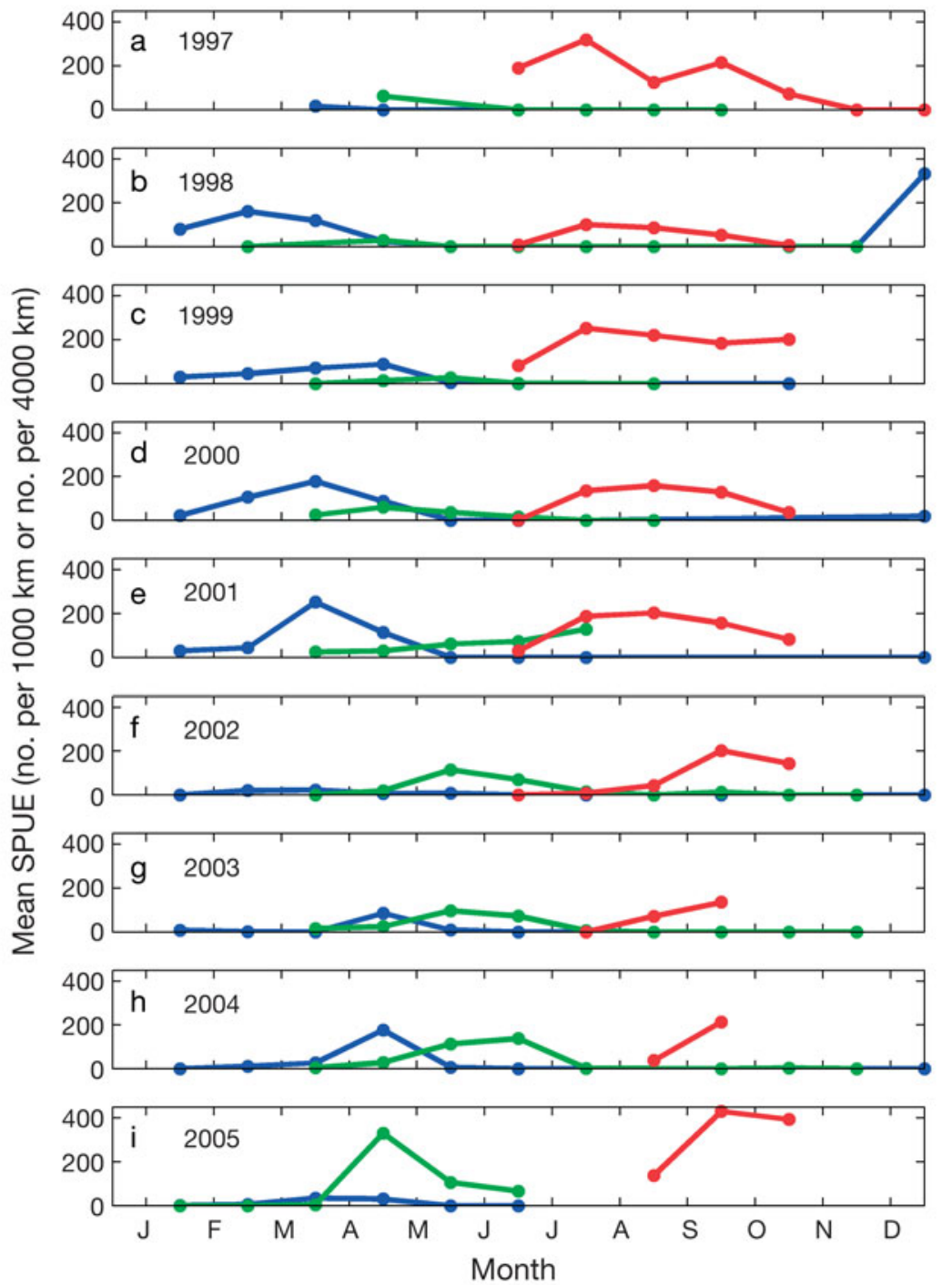

Fig. 3. Average right-whale sightings per unit effort (SPUE) in each of the highuse areas, grouped by year for (a) 1997, (b) 1998, (c) 1999, (d) 2000, (e) 2001, (f) 2002, (g) 2003, (h) 2004, and (i) 2005. All years show a consistent pattern of transition from Cape Cod Bay $(-\bullet)$ to Great South Channel $(-\rightarrow)$ to Bay of Fundy (-) as the seasons progress from winter through summer. Mean SPUE data for Cape Cod Bay and the Great South Channel are shown with a 4 -fold different scale (no. per $4000 \mathrm{~km}$ ) than that for the Bay of Fundy (no. per $1000 \mathrm{~km}$ ) to emphasize transitions

May and June, and depart by July. The year 2005 was an anomalous year in that right whales arrived earlier and abundance was exceptionally high in April.

Bay of Fundy. Because of the distribution of survey effort (almost none in May or November), arrival to and departure from the Bay of Fundy are not well resolved in this data set (Figs. 2 \& 3). The SPUE data do show, however, that right whales are most abundant between July and September for each year from 1997 to 2005. Interestingly, SPUE values in the Bay of Fundy are the highest of the 4 high-use habitat areas.
Roseway Basin. Roseway Basin, an area previously identified as an important habitat for right whales, was characterized by relatively high SPUE levels. However, during the period of the present study, the distribution of survey effort was very uneven with poor temporal coverage. Unfortunately, the sparse SPUE data in Roseway Basin precludes a detailed examination of this area for the quantitative assessment of right-whale habitat characteristics (Fig. 2). Thus, this area was not included in the development of the cumulative right-whale nutritional index.

\section{SeaWiFS chl variability}

We used time series of chl extracted from weekly and monthly (Fig. 4) composite SeaWiFS observations to examine the high concentration of phytoplankton (or bloom period) for each year from 1998 to 2006 in the 4 high-use areas that were defined by analysis of SPUE distributions (black outlines in Fig. 1). Although the exact timing and duration of blooms vary within each region, there is an overall seasonal progression, with highest chl concentration shifting from Cape Cod Bay to the Great South Channel to the Bay of Fundy as the seasons progress from winter to summer (Fig. 5).

Cape Cod Bay. Cape Cod Bay is characterized by presence of both spring and fall blooms, although their prominence varies from year to year (Fig. 4). The timing of onset and decline of the blooms is also variable from year to year. Typically, lowest chl concentrations occur in summer between the bloom periods. Of all the areas, Cape Cod Bay has the highest chl concentrations.

Great South Channel. The dominant feature in the Great South Channel is a spring bloom (Fig. 4). The amplitude varies from year to year, but the highest chl concentrations always occur in April. Very prominent blooms occurred in 1999, 2000, and 2004.

Bay of Fundy. A distinct feature in the Bay of Fundy is an extended summer bloom (Fig. 4). These blooms last $\geq 6 \mathrm{mo}$, often with 2 distinguishable maxima, usually separated by 3 to $4 \mathrm{mo}$. In this area, the lowest chl concentrations occur during the period spanning late fall to early spring. 

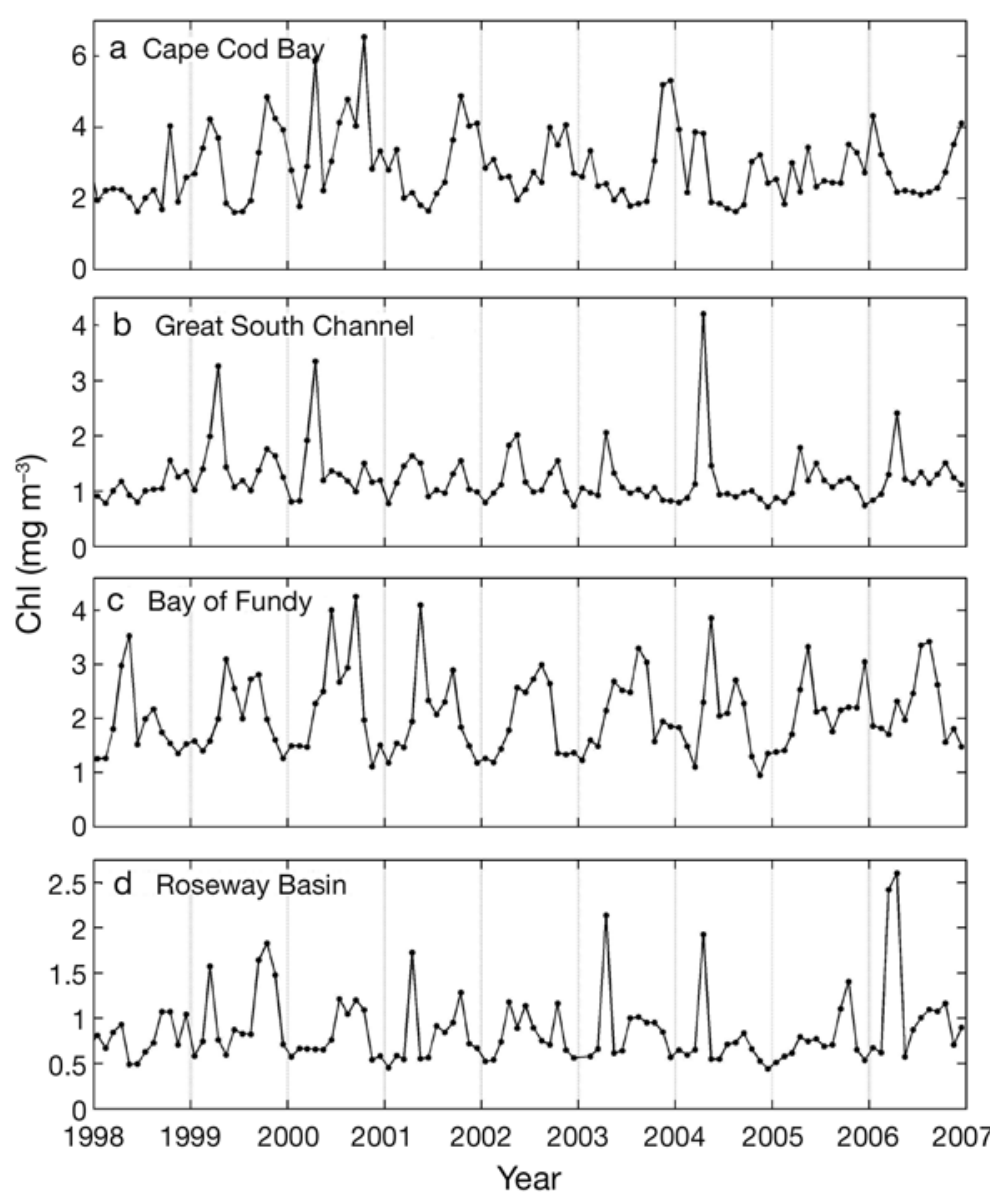

Fig. 4. For each high-use area: (a) Cape Cod Bay, (b) Great South Channel, (c) Bay of Fundy, and (d) Roseway Basin, 9 yr time series of average chlorophyll (chl) concentration, extracted from monthly composite SeaWiFS observations

Roseway Basin. During the present study period, Roseway Basin typically had the lowest chl of all the areas, with concentrations especially low during winter (Fig. 4). In most years, Roseway Basin has spring and fall blooms, though 2000 was an anomalous year in that no spring bloom occurred.

\section{Mean seasonal cycle comparison}

Comparison of the monthly-resolved mean annual cycle for SeaWiFS-derived chl and SPUE in each of the high-use areas shows notable patterns. The results of the SPUE analysis, for the period from 1997 to 2005, emphasize that highest density right-whale sightings progress from Cape Cod Bay to the Great South Channel to the Bay of Fundy (Fig. 5, right panels). The sightings are too sparse in Roseway Basin to constrain a mean annual cycle for these years. This pattern of transition is consistent with the seasonal progression of peak chl concentrations. Within the broadly defined feeding season (late winter through early fall), highest concentrations are observed throughout the winter and early spring in Cape Cod Bay, from March to May in the Great South Channel, and throughout the summer in the Bay of Fundy (Fig. 5, left panels).

\section{Annual weighted chl index and calf count}

While patterns of whale distribution may be related to chl distributions on seasonal time scales, we expect annual or longer time scales to influence reproductive success (number of calves observed). This led us to consider an annual weighted chl index. We used the details of the mean annual cycles to select the time ranges contributing to the annual weighted chl concentration. The bloom periods, capturing highest chl concentrations, were averaged within Cape Cod Bay (January to April), the Great South Channel (March to May), and the Bay of Fundy (May to October), such that the relevant monthly period is coincident with peak right-whale sightings in each of the high-use areas. The resulting annual weighted chl concentration (which represents 1 realization of a nutritional index) shows interannual variability over the period 1997 to 2006 with an intriguing relationship to the number of right whale calves observed (Fig. 6). There is a significant positive correlation between the number of calves produced and weighted chl averaged over 2 prior years (Fig. $7 \mathrm{c}, \mathrm{r}=0.71, \mathrm{p}=0.049$ ). There are also positive but not significant (at $p=0.05$ ) correlations for weighted chl with a $1 \mathrm{yr}$ lag (Fig. 7a, r = 0.39, p=0.306) and 2 yr lag (Fig. 7b, r = 0.66, p=0.075).

The 2 yr average of annual weighted chl concentration (encompassing the whale's resting year and gestation year) may have predictive capability. For example, the highest calf numbers, in 2001 and 2005, were observed $1 \mathrm{yr}$ after the $2 \mathrm{yr}$ average of highest weighted chl values (1999 to 2000 and 2003 to 2004). For the entire period of study (all points included), the 2 yr weighted chl explains $50 \%$ of the variance in the number of calves produced the next year (Fig. $7 \mathrm{C}$ ).

\section{DISCUSSION}

The results of the right-whale SPUE analysis highlight seasonal time periods of dense whale sightings in 

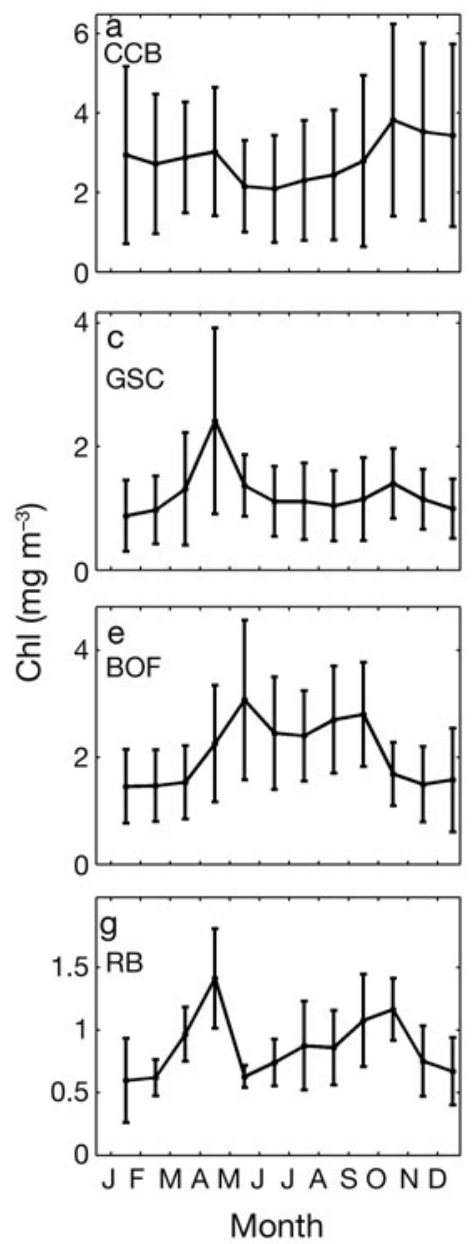

Fig. 5. Comparison of monthly-resolved mean cycle for SeaWiFS-derived chlorophyll (chl) and for sightings per unit effort (SPUE) in each of the highuse areas: (a,b) Cape Cod Bay (CCB), (c,d) Great South Channel (GSC), (e,f) Bay of Fundy (BOF), and (g) Roseway Basin (RB). Highest density rightwhale sightings progress from $\mathrm{CCB}$ to GSC to BOF and are consistent with the seasonal progression of highest chl concentrations

3 high-use areas in the Northwest Atlantic: Cape Cod Bay, the Great South Channel, and the Bay of Fundy. For the period 1997 to 2005, whale sightings are most abundant in these 3 regions during characteristic months and show seasonal progression from Cape Cod Bay to the Great South Channel to the Bay of Fundy. This seasonal progression is consistent with the transition of peak satellite-derived chl concentrations in each of the high-use areas that were defined by the SPUE analysis (Fig. 6). The range of patterns in chl seasonality evident in these areas is similar to previous reports by Thomas et al. (2003) for a different selection of geographic locations within and around the Gulf of Maine. When compared to Thomas et al.'s (2003) locations, our results highlight Cape Cod Bay as an extreme case of relatively high wintertime concentrations, a seasonal pattern generally more consistent with the Middle Atlantic Bight than the Gulf of Maine (Yoder et al. 2002).

Winn et al. (1986) were the first to propose a 6-phase model of the right whale's annual migratory cycle. The model describes the general population movements of the right whales. During the winter, most reproductively active females give birth along the coasts of Georgia and northeastern Florida. Non-calving females and males, on the other hand, are rarely seen in the calving grounds and their locations during the early winter remain largely unknown (Kenney et al. 2001). As the seasons progress, the reproducing females migrate northward and join with the rest of the population in the late winter or early spring, remaining in the feeding habitats through summer and fall. Although variability is evident, our analysis of recent right-whale SPUE distribution is consistent with the movements and patterns initially set forth in Winn et al.'s (1986) framework.

To sustain their large metabolic demands, right whales migrate to habitat areas containing their food source and forage on dense prey patches. Winn et al. (1986) hypothesized that the seasonal progression of the right whale's migratory cycle coincides with high-density concentrations of their principal prey, Calanus finmarchicus. Numerous studies conducted in each of the major feeding habitats have confirmed that right whale's feeding activity is directed towards locating and exploiting dense patches of C. finmarchicus (Baumgartner \& Mate 2003, Baumgartner et al. 2003). Though exciting progress is being made, the oceanographic conditions that promote dense patches of this prey over time and space remain poorly understood, as do the migration and foraging strategies the right whales use to locate and exploit these food resources (Kenney et al. 2001). Nevertheless, we do know that, during late winter and early spring, right whales are found feeding in coastal waters of Cape Cod Bay when their zooplankton food source is at a maximum, and whales typically leave the area, presumably in search of a better food supply, as their prey sources start to decrease (Mayo \& Marx 1990). Likewise, right whales feed in the Great South Channel during late spring (Kenney \& Wishner 1995, Beardsley et al. 1996) and the Bay of Fundy during the summer months (Murison \& Gaskin 1989, Woodley \& Gaskin 1996, Baumgartner \& Mate 2003) when highdensity concentrations of $C$. finmarchicus occur. 


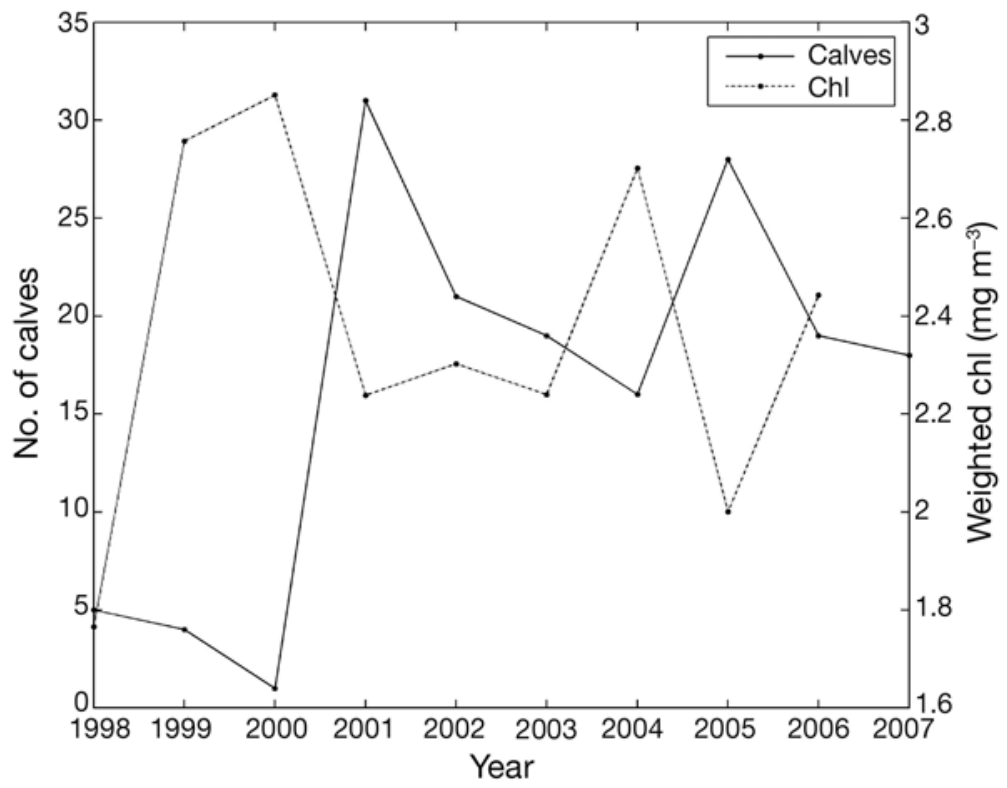

Fig. 6. Time series of number of calves observed (solid line) and annual weighted SeaWiFS chl (dashed line). The $2 \mathrm{yr}$ with highest calf numbers are observed 1 to 2 yr after the highest weighted chl values. Chl values are weighted such that bloom periods, capturing highest chl concentrations, were averaged within Cape Cod Bay (January to April), the Great South Channel (March to May), and the Bay of Fundy (May to October) to ensure that the relevant monthly period overlaps with peak whale sightings in each of the high-use areas defined by the sightings per unit effort (SPUE) analysis

The right whale's zooplankton food source, Calanus finmarchicus, is a direct consumer of phytoplankton. Therefore, the timing of phytoplankton abundance and biomass development in each of the right-whale feeding habitats could have important consequences, especially since $C$. finmarchicus shows signs of food limitation in areas of low surface-chl concentration (Campbell et al. 2001). We found that the temporal pattern of right-whale movement between feeding areas is consistent with changes in satellite-derived chl concentrations in those areas, which may reflect an impact through C. finmarchicus populations. As the seasons progress from winter to summer, the highest chl concentrations are observed throughout winter and early spring in Cape Cod Bay, from March to May in the Great South Channel, and throughout the summer in the Bay of Fundy. While we cannot quantify the effect of this progression on C. finmarchicus distributions, it seems likely that post-bloom conditions will impact C. finmarchicus, for instance contributing to spatial and temporal variability in development rate or the onset of diapause (e.g. Durbin et al. 2000, 2003). We emphasize that our analysis and interpretation is not meant to imply that $C$. finmarchicus (and right whales in turn) consistently feed on local surface-layer phytoplankton that are accessible to satellite-based observa- tion. Copepods in the Gulf of Maine are well known to form deep layers, especially late in the season when right whales have also been documented to exploit those layers (Baumgartner \& Mate 2003, Baumgartner et al. 2007). The intensity and timing of near-surface blooms may influence deep layers but through a complex set of factors not explicit in our analysis. Furthermore, surface chl concentrations and copepod aggregations are both influenced by some of the same oceanographic conditions, such as level of stratification and presence of fronts that vary with season and year. It may be that relationships between whales and chl patterns emerge because of this kind of covariance.

When we averaged annual weighted chl concentration over the 2 yr period prior to calving, encompassing the resting year and the gestational year for the reproductive females, half of the variation in breeding success can be explained (Fig. 7c). There is also a suggestive trend with a single 1 yr lag, but with a strong outlier year (calves in 2000) for that case (Fig. 7a). Considering potential food availability over the 2 yr span may shed some light on the patterns that are not well explained by a single-year lag. For instance, the lowest number of calves (1 calf in 2000) was observed $2 \mathrm{yr}$ after the lowest annual weighted chl value (i.e. chl observations in 1998, during the whale's resting period). Even though high chl conditions returned in 1999, the time-lagged response (to successful reproduction) may have been hampered by extremely low food availability during the whale's resting period, possibly delaying conception. Periods of extreme food limitation might affect a female's response to previous successful reproduction by prolonging the crucial time needed to recover. It is likely that a threshold food requirement and associated body condition during the resting year must be met before successful conception and early pregnancy can occur. If food conditions in a given year are below this threshold (as may be the case during 1998, with weighted $\mathrm{chl}<2 \mathrm{mg} \mathrm{m}^{-3}$ ), then it is possible that food conditions during the subsequent year do not control calf production since the minimum requirements for conception and early pregnancy were not met. Longer time series are needed to evaluate whether these kinds of factors contribute to consistent patterns in the relationship between chl and reproductive success (number of calves observed).

When calf numbers are lagged by 1 yr (Fig. 7a), weighted chl concentration has less predictive power 

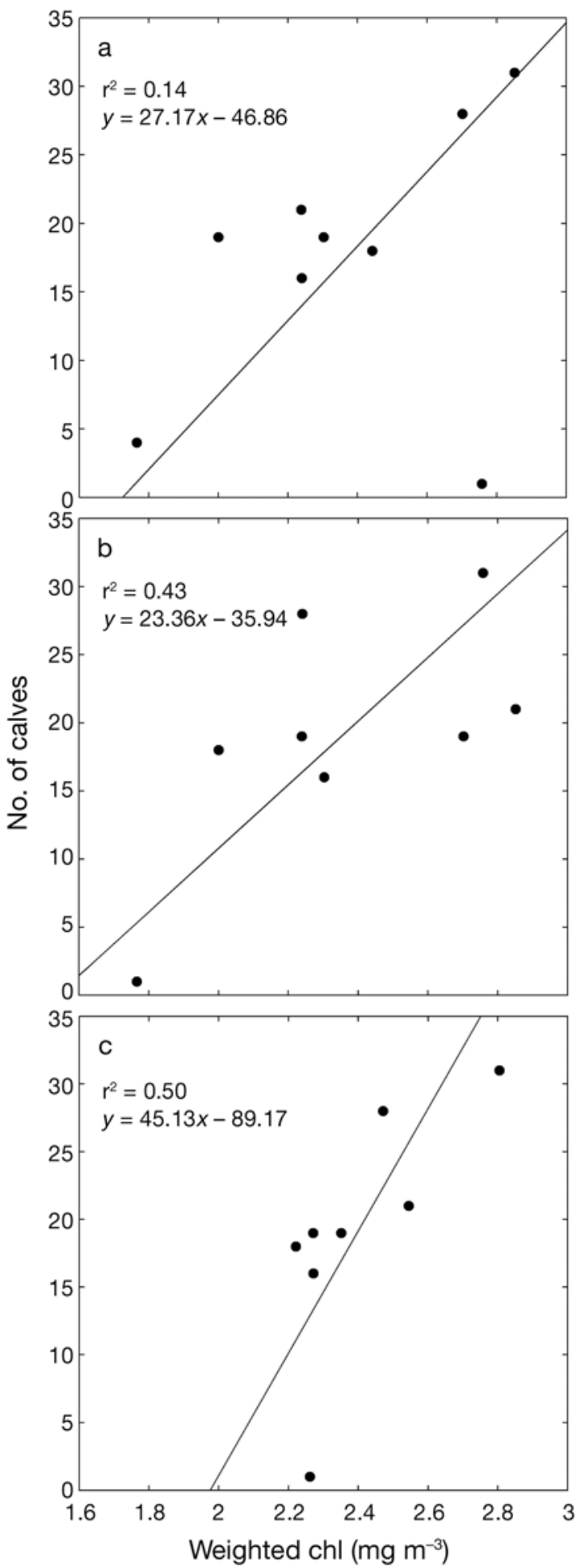

Fig. 7. Relationship between number of calves observed and annual weighted chlorophyll (chl) with (a) 1 yr lag in calf numbers, (b) 2 yr lag in calf numbers, and (c) chl averaged over the 2 yr prior to calving. With a 1 yr lag and a 2 yr lag, weighted chl explains $14 \%(p=0.306)$ and $43 \%(p=0.075)$ of the variance in the number of calves, respectively. The $2 \mathrm{yr}$ averaged chl explains $50 \%(p=0.049)$ of the variance in the number of calves produced the next year than when a 2 yr lag is considered (Fig. 7b), with weighted chl concentration (during the mother's resting year) explaining $43 \%(p=0.075)$ of the variance in number of calves produced; this result may reflect that gestation itself is not especially costly, while the energetic demands for lactation are substantial. This idea is consistent with observations for another cetacean, the harbor porpoise, in which costs of lactation are 3 times greater than for pregnancy (Yasui \& Gaskin 1986). Given the fact that mother right whales utilize their blubber reserves for energetic support during reproduction (Angell 2005), it is possible that they do not conceive until they have enough energy reserved to make it through lactation. Because of the challenges studying cetaceans in their natural habitats, detailed mechanisms leading to reproductive delays (i.e. failure to conceive, failure to carry to term, low survival of neonates) remain poorly constrained, but there is welldocumented variability in calving interval (Kraus et al. 2007) and established links between body condition and reproduction in right whales (Moore et al. 2001, Angell 2005). Our findings provide further support for a general link with food availability.

It is surprising that a single factor, such as $2 \mathrm{yr}$ weighted chl, might explain so much of the variation in right-whale reproductive success. Right-whale biology and ecological interactions are well known to be more complex than this view encompasses. Nonetheless, our results support the view that surface chl concentration, especially as sampled with the resolution possible from earth-orbiting satellites, provides a practical means to integrate broadly over a range of factors directly affecting the right-whale population. It may not be necessary to resolve all the links or complexity involved in the relationship between primary producers and whales to identify relevant indices.

The underlying premise motivating the present study is that reproductive success in the North Atlantic right whale is limited by food availability for which surface chl conditions may be a working proxy. The evidence of a relationship between 2 yr average weighted chl (i.e. a nutritional index) and the number of new right-whale calves is consistent with this idea. For the present study period, the most successful years for reproduction (i.e. 2001 and 2005) follow years with highest weighted chl values averaged over $2 \mathrm{yr}$, and unsuccessful years (i.e. 1999 and 2000) occur when weighted chl was very low during at least 1 of the 2 preceding years. Years of extreme food limitation may delay a mother's response to successful reproduction by prolonging the crucial time needed to store surplus energy for the next healthy pregnancy.

The mechanistic links between chl and right-whale feeding success are complicated and mediated by a variety of biological and environmental processes. 
They depend on many factors, including the complex life history and ecology of prey species such as Calanus finmarchicus and behavioral and physical oceanographic conditions that affect prey aggregation into dense patches critical for effective whale feeding (e.g. Baumgartner et al. 2007). These factors can be quantified only in the context of detailed process studies, which are necessarily limited in spatial and temporal resolution. The notable advantage of remote-sensing approaches is that they allow wide ranges of time and space to be assessed. Future efforts that exploit a combination of these approaches may provide new insights.

While the present study is based on a relatively simple analysis of the first $9 \mathrm{yr}$ of ocean-color data obtained from the SeaWiFS mission, these data provide a unique synoptic quantification of seasonal variability in chl concentration within the right-whale feeding grounds in the Northwest Atlantic. A longer time series is critical to examine the generality of predictive relationships between weighted chl concentration and calf production. Data from the next generation of global ocean-color missions (e.g. moderate-resolution imaging spectroradiometer [MODIS], medium-resolution imaging spectrometer [MERIS]) will provide an opportunity for further analysis. These new satellite data sets, which overlap with and are expected to extend beyond the SeaWiFS mission, could improve our understanding of right-whale reproduction and its environmental regulation. Longer time series will also enable more complex uses of satellite-derived chl observations. For instance, it may be desirable to enhance demographic models (e.g. Fujiwara \& Caswell $2001)$ to explicitly incorporate a remotely sensed measure of food availability and to represent its impact on particular life-cycle stages (Greene et al. 2003). This kind of approach would allow us to move away from simple correlation analyses and to more carefully consider the biological and ecological implications of food availability on right-whale populations.

More complex correlations among basin-scale phenomena associated with changes in the North Atlantic Oscillation, regional physical oceanography, and the abundance of Calanus finmarchicus within the rightwhale feeding grounds reveal that climate-driven changes may account for some of the variability in C. finmarchicus abundance, with possible consequences for right-whale calving rates (Greene \& Pershing 2004, Baumgartner et al. 2007). With a longer time series of sea-surface chl, it will be possible to extend these analyses to include relevant aspects of phytoplankton variability and to investigate the strength of bottom-up control.

Emerging approaches for characterizing spatial and temporal variability in right-whale distributions may also facilitate further applications of high-resolution remotely sensed observations. For instance, new sampling technologies in the form of passive acoustic devices ('pop-ups') have been employed in the field to study the seasonal occurrence and distribution of right whales in the North Atlantic (Parks \& Clark 2005). These passive acoustic methods have the potential to augment visual observations from aerial and shipboard surveys, enabling a sharper definition of the arrival and departure times for each habitat. The integration of whale distribution data, from both visual and acoustic measures, with concurrent satellite-derived chl observations, will provide a better understanding of the migration patterns and habitats of right whales, ultimately assisting in the management of this highly endangered species.

Acknowledgements. We appreciate the commitment of S. D. Kraus, director of the right-whale research program at the New England Aquarium, and the wonderful research groups who are dedicated to monitoring right-whale populations, including calf production. Access to the whale sightings and survey database at University of Rhode Island and the calving summary data at the New England Aquarium were provided through the North Atlantic Right Whale Consortium (www.rightwhaleweb.org). The bulk of the surveys that went into the sightings per unit effort data were conducted by the New England Aquarium (Boston, Massachusetts), Provincetown Center for Coastal Studies (Provincetown, Massachusetts), National Marine Fisheries Service Northeast Fisheries Science Center (Woods Hole, Massachusetts), and East Coast Ecosystems Research Organization (Pierrefonds, Quebec). This research was supported by grants from the Northeast Consortium and the Ocean Biology and Biogeochemistry Program at NASA.

\section{LITERATURE CITED}

Allen GM (1916) The whalebone whales of New England. Mem Boston Soc Nat Hist 8:107-322

Angell CM (2005) Body fat condition of free-ranging right whales, Eubalaena glacialis and Eubalaena australis. PhD dissertation, Boston University

Baumgartner MF, Mate BR (2003) Summertime foraging ecology of North Atlantic right whales. Mar Ecol Prog Ser 264:123-135

Baumgartner MF, Cole TVN, Campbell RG, Teegarden GJ, Durbin EG (2003) Associations between North Atlantic right whales and their prey, Calanus finmarchicus, over diel and tidal time scales. Mar Ecol Prog Ser 264:155-166

Baumgartner MF, Mayo CA, Kenney RD (2007) Enormous carnivores, microscopic food, and a restaurant that's hard to find. In: Kraus SD, Rolland R (eds) The urban whale: North Atlantic right whales at the crossroads. Harvard University Press, Cambridge, MA, p 138-171

Beardsley RC, Epstein AW, Chen C, Wishner KF, Macaulay MC, Kenney RD (1996) Spatial variability in zooplankton abundance near feeding right whales in the Great South Channel. Deep-Sea Res II 43:1601-1625

> Campbell JW (1995) The lognormal distribution as a model for bio-optical variability in the sea. J Geophys Res 100: 13237-13254

Campbell RG, Runge JA, Durbin EG (2001) Evidence for food 
limitation of Calanus finmarchicus production rates on the southern flank of Georges Bank during April 1997. DeepSea Res II 48:531-549

Caswell H, Fujiwara M, Brault S (1999) Declining survival probability threatens the North Atlantic right whale. Proc Natl Acad Sci USA 96:3308-3313

CETAP (Cetacean and Turtle Assessment Program) (1982) A characterization of marine mammals and turtles in the mid- and north Atlantic areas of the U.S. outer continental shelf. Report no. AA551-CT8-48. Bureau of Land Management, Washington, DC

Crain JA, Miller CB (2001) Effects of starvation on intermolt development in Calanus finmarchicus copepodites: a comparison between theoretical models and field studies. Deep-Sea Res II 48:551-566

Cushing DH (1975) Marine ecology and fisheries. Cambridge University Press, Cambridge

Cushing DH (1990) Plankton production and year-class strength in fish populations: an update of the match/mismatch hypothesis. Adv Mar Biol 26:249-293

Durbin EG, Garrahan PR, Casas MC (2000) Abundance and distribution of Calanus finmarchicus on the Georges Bank during 1995 and 1996. ICES J Mar Sci 57:1664-1685

Durbin EG, Campbell RG, Casas MC, Ohman MD, Niehoff B, Runge J, Wagner M (2003) Interannual variation in phytoplankton blooms and zooplankton productivity and abundance in the Gulf of Maine during winter. Mar Ecol Prog Ser 254:81-100

Frisch RE (1984) Body fat, puberty and fertility. Biol Rev Camb Philos Soc 59:161-188

Fu G, Baith KS, McClain CR (1998) SeaDAS: the SeaWiFS data analysis system. Proc 4th Pacific Ocean Remote Sensing Conf, Qingdao, China, July 28-31, 1998, p 73-79

Fujiwara M, Caswell H (2001) Demography of the endangered right whale. Nature 414:537-541

Gaskin DE (1991) An update on the status of the right whale, Eubalaena glacialis, in Canada. Can Field Nat 105: 198-205

Gordon HR, Clark DK (1980) Remote sensing optical properties of a stratified ocean: an improved interpretation. Appl Opt 20:3426-3428

Greene CH, Pershing AJ (2004) Climate and the conservation biology of North Atlantic right whales: the right whale at the wrong time? Front Ecol Environ 2:29-34

Greene CH, Pershing AJ, Kenney RD, Jossi JW (2003) Impact of climate variability on the recovery of endangered North Atlantic right whales. Oceanography 16:98-103

> Gregg WW, Casey NW (2004) Global and regional evaluation of the SeaWiFS chlorophyll data set. Remote Sens Environ 93:463-479

Hamilton PK, Martin SM (1999) A catalog of identified right whales from the North Atlantic: 1935-1997. New England Aquarium, Boston, MA

Hooker SB, McClain CR (2000) The calibration and validation of SeaWiFS data. Prog Oceanogr 45:427-465

Hyde KJW, O'Reilly JE, Oviatt CA (2007) Validation of SeaWiFS chlorophyll a in Massachusetts Bay. Cont Shelf Res 27:1677-1691

IWC (International Whaling Commission) (2001) Report of the workshop on status and trends of western North Atlantic right whales. J Cetacean Res Manag 2(Spec Issue):61-87

Kenney RD (2001) The North Atlantic Right Whale Consortium databases. Maritimes 43:3-5

Kenney RD, Winn HE (1986) Cetacean high-use habitats of the northeast U.S. continental shelf/slope areas. Fish Bull (Wash DC) 84:345-357

Kenney RD, Wishner KF (1995) The south channel ocean pro- ductivity experiment. Cont Shelf Res 15:373-384

Kenney RD, Mayo CA, Winn HE (2001) Migration and foraging strategies at varying spatial scales in western North Atlantic right whales: a review of hypotheses. J Cetacean Res Manag 2(Spec Issue):251-260

Knowlton AR, Kraus SD (2001) Mortality and serious injury of northern right whales (Eubalaena glacialis) in the western North Atlantic Ocean. J Cetacean Res Manag 2(Spec Issue):193-208

Knowlton AR, Kraus SD, Kenney RD (1994) Reproduction in North Atlantic right whales, Eubalaena glacialis. Can J Zool 72:1297-1305

Kraus SD, Hamilton PK, Kenney RD, Knowlton AR, Slay C (2001) Status and trends in reproduction of the North Atlantic right whale. J Cetacean Res Manag 2(Spec Issue): 231-236

Kraus SD, Brown MW, Caswell H, Clark CW and others (2005) North Atlantic right whales in crisis. Science 309: 561-562

Kraus SD, Pace RM III, Frasier TR (2007) High investment, low return: the strange case of reproduction in Eubalaena glacialis. In: Kraus SD, Rolland RM (eds) The urban whale: North Atlantic right whales at the crossroads. Harvard University Press, Cambridge, MA, p 172-199

Lavender SJ, Pinkerton MH, Froidefond JM, Morales J, Aiken J, Moore GF (2004) SeaWiFS validation in European coastal waters using optical and bio-geochemical measurements. Int J Remote Sens 25:1481-1488

Lockyer C (1986) Body fat condition in Northeast Atlantic fin whales, Balaenoptera physalus, and its relationship with reproduction and food resource. Can J Fish Aquat Sci 43: 142-147

Mayo CA, Marx MK (1990) Surface foraging behavior of the North Atlantic right whale, Eubalaena glacialis, and associated zooplankton characteristics. Can J Zool 68: 2214-2220

Moore MJ, Miller CA, Morss MS, Arthur R and others (2001) Ultrasonic measurement of blubber thickness in right whales. J Cetacean Res Manag 2(Spec Issue):301-309

Murison LD, Gaskin DE (1989) The distribution of right whales and zooplankton in the Bay of Fundy, Canada. Can J Zool 67:1411-1420

O'Reilly JE, Maritorena S, Mitchell BG, Siegel DA and others (1998) Ocean color chlorophyll algorithms for SeaWiFS. J Geophys Res 103:24937-24954

O'Reilly JE, Maritorena S, Siegel DA, O'Brien M and others (2000) Ocean color chlorophyll a algorithms for SeaWiFS, OC2, and OC4, Version 4. In: Hooker SB, Firestone ER (eds) SeaWiFS postlaunch technical report series, Vol 11. SeaWiFS postlaunch calibration and validation analyses, Part 3. NASA, Greenbelt, MD, p 9-23

Parks SE, Clark CW (2005) Variation in acoustic activity of North Atlantic right whales in three critical habitat areas in 2004. J Acoust Soc Am 117:2469

> Platt T, Fuentes-Yaco C, Frank KT (2003) Spring algal bloom and larval fish survival. Nature 423:398-399

Reeves RR, Rolland R, Clapham PJ (2001) Causes of reproductive failure in North Atlantic right whales: new avenues of research. Report of a workshop held 26-28 April 2000, Falmouth, MA. Ref. doc. 01-16. Northeast Fisheries Science Center, Woods Hole, MA

> Shoop CR, Kenney RD (1992) Seasonal distributions and abundances of sea turtles off the northeastern United States. Herpetol Monogr 6:43-67

Sokal RR, Rohlf J (1981) Biometry: the principles and practice of statistics in biological research. WH Freeman, San Francisco, CA 
Thomas VG (1990) Control of reproduction in animal species with high and low body fat reserves. In: Frisch RE (ed) Adipose tissue and reproduction, Vol 14. Karger, Basel, p 27-41

Thomas AC, Townsend DW, Weatherbee R (2003) Satellitemeasured phytoplankton variability in the Gulf of Maine. Cont Shelf Res 23:971-989

Townsend DW, Cucci CL, Berman T (1984) Subsurface chlorophyll maxima and vertical distribution of zooplankton in the Gulf of Maine. J Plankton Res 6:793-802

Winn HE, Price CA, Sorensen PW (1986) The distributional biology of the right whale (Eubalaena glacialis) in the western North Atlantic. Rep Int Whal Comm Spec Issue 10:129-138

Editorial responsibility: Matthias Seaman,

Oldendorf/Luhe, Germany
Wishner KF, Schoenherr JR, Beardsley R, Chen C (1995) Abundance, distribution and population structure of the copepod Calanus finmarchicus in a springtime right whale feeding area in the southwestern Gulf of Maine. Cont Shelf Res 15:475-507

Woodley TH, Gaskin DE (1996) Environmental characteristics of North Atlantic right and fin whale habitat in the lower Bay of Fundy, Canada. Can J Zool 74:75-84

Yasui WY, Gaskin DE (1986) Energy budget of a small cetacean. Ophelia 25:183-197

Yoder JA, Schollaert SE, O'Reilly JE (2002) Climatological phytoplankton chlorophyll and sea-surface temperature patterns in continental shelf and slope waters off the Northeast U.S. coast. Limnol Oceanogr 47:672-682

Submitted: October 25, 2007; Accepted: August 11, 2009

Proofs received from author(s): November 8, 2009 